\title{
Retinoblastoma cT1a TNM Finding v7
}

National Cancer Institute

\section{Source}

National Cancer Institute. Retinoblastoma CT1a TNM Finding v7. NCI Thesaurus. Code C88755.

No tumor in either eye is greater than $3 \mathrm{~mm}$ in largest dimension or located closer than $1.5 \mathrm{~mm}$ to the optic nerve or fovea. (from AJCC 7th Ed.) 